\title{
Social Challenges Learners Residing in Informal Settlements in Katima Mulilo Town Face in Learning
}

\author{
Eugene Maemeko ${ }^{1}$, Muzwa Mukwambo ${ }^{1} \&$ David Nkengbeza ${ }^{1, *}$ \\ ${ }^{1}$ Faculty of Education, University of Namibia, Katima Mulilo Canpus, Namibia \\ *Correspondence: Faculty of Education, University of Namibia, Katima Mulilo, Namibia. E-mail: \\ dnkengbeza@unam.na
}

Received: April 16, 2021

Accepted: June 22, $2021 \quad$ Online Published: August 3, 2021

doi:10.5430/jct.v10n3p36

URL: https://doi.org/10.5430/jct.v10n3p36

\begin{abstract}
The purpose of this article was to find out social challenges learners residing in informal settlements in Katima Mulilo Town face. Informal settlements crop up as people move from rural settings to urban areas as they seek better facilities, a process known as urbanisation. However, not all who migrate into urban areas end up getting the required facilities. This result in some finding residence in informal settlements where conditions are deplorable and as a result brings some social challenges to learning. This article's objective is to explore the social challenges learners residing in informal settlements face in learning. The article also seeks possible ways to deal with the social challenges in order to make learning possible. To come up with response to the questions, the study adopted a qualitative research approach. Instruments used to generate data were observation and interviews. To support the data generated from the participants, the learners, the social capital theory and urban theories were used. Some of the social challenges found to impede learning include poverty, flooding, expensive water and electricity bills, limited sewage disposal system, unfair relocations, poor sanitation, unemployment and high crime rate. Solutions were also suggested on how to overcome these challenges.
\end{abstract}

Keywords: informal settlement, challenges, Katima Mulilo, education, learning

\section{Introduction}

In this study social challenges which are brought about during urbanization, a phenomenon characterised by a rise in the number of people residing in cities or urban centers, as Bodo (2019) views is explored. The objective is to see the social challenges learners residing in informal settlements face when they come to learn as people who migrate, end up seeking residence in informal settlement. The background discusses the phenomenon of urbanisation which brings social challenges to learners who end up residing in informal settlements. After, the research problem and research questions are stated. The methodology, data presentation and analysis, discussion and conclusion are presented.

\subsection{Background}

Urbanisation is not a phenomenon only found in Namibia, Katima Mulilo where the study took place. However, it is found in all urban areas in Namibia and globally but affecting most in particular developing nations of which Namibia is one Bodo (2019). Migration to urban areas where people end up staying in deplorable conditions in informal settlements can be explained using the self - generated urbanisation Hawley (1981); modernisation Smith (1996); dependency Kasarda and Crenshaw (1991) or urban bias Bradshaw (1987) theories.

People move to cities and towns, rural to urban migration Bodo (2015) in search of better paid jobs, better education, better living standards, better health care services, better housing and for better entertainments and is what the self generated urbanisation theory Hawley (1981) proposes. Huchzemeyer (2008) also supports this theory. People moved in big numbers for most the above reasons without considering the consequences of this movement Jiusto (2012) and as a result end up residing in informal settlements where their dependents, the learners encounter social challenges when they come to learn. This movement consist of different people such as the educated, less educated and uneducated, and the competition of employment becomes high and as a result only a few of these people finally get jobs. People who could not afford a better life because they have no jobs are forced to build squatter camps at the 
edge of the town. In the case of Katima Mulilo where the study took place we have places like informal settlement one, two, three, four and five. Informal settlement one is inhabited by people who were relocated by the town council from Piggery in 1995. People who are living in these locations face social challenges like in any other informal settlement in Namibia and globally. Informal settlement one is the largest informal settlement in Katima Mulilo town.

People also undergo rural to urban migration as they seek modernized areas such as places where the reception of their technological devices operate well on account of reliable network and this is what the modernization theory views (Smith, 1996). It differs with the self - generated urbanisation theory in that it can be a migration on the level of rural to urban transformation. Rural to urban transformation as a cause of migration is triggered by the presence of a place in the rural area where people migrate to get the facilities which they cannot get in their original places. For instance, if a rural setting is installed with an antenna to boost the reception of communication gadgets, the population tend to go and reside in such areas.

On the other hand the dependency theory by Kasarda and Crenshaw (1991) proposes comes through either global coercion or through the natural logic of capitalistic policies in given areas; and also the existence of underdevelopment among the population (Wallerstein, 1980). For instance, when in an area where people are experiencing the adverse effects of capitalistic policies or non-democratic measures, they migrate to other states or countries where conditions are better. Finally, the urban bias theory Bradshaw (1987) proposes comes as a result of uneven distribution of resources whereby the urban tend to have more resources which are cheaper than those found in rural settings. In some cases, this uneven distribution can be attributed to governments taxing rural dwellers heavily. As a result of this, commodities in these rural setting become expensive and the option they remain with is to move into urban centres where life is relatively better. In the process of migration they end up residing in squatter like camps where learning for their dependence is compromised because of the social challenges they encounter. This comes as a challenge to teachers who are at school and the management of the school where these learners attend school.

\subsection{Problem Statement}

One of the biggest challenges faced in Katima Mulilo Town is the increase in the number of people moving into the town and illegally residing in its informal settlements in search of jobs and better living standards. Most of the people living in these informal settlements live under poor conditions. Most of their houses, the walls and roof are built with corrugated iron sheets or pole and dagga on walls and roof with corrugated iron sheets. These houses are close to each other and usually small, but accommodate more than five people; hence such deplorable conditions interfere with learning activities of learners residing in such areas. Coupled with lack of clean piped water for people to drink, poor roads, lack of toilets for people to use when nature calls, poor electricity connection to the dwellings makes life very miserable to the learners who reside in these deplorable locations. In the event that the basics for human survival are not in place, the most affected are learners who reside in these areas. Learners have a dual encounter of social challenges at their places of residence and the same social challenges can spill into the schooling system, hence affecting learning. Under these circumstances which learners come with, school management and teachers are not spared from these social challenges learners bring to school. This study then found it worthy to understand the social challenges learners residing in informal settlements face and how they can be mitigated as it comes as a problem involving three parts in the schooling system - the learners, the school management/leadership and the teachers. This phenomenon is not only peculiar in Katima Mulilo Town where the study took place, but also in other towns in Namibia and other developing countries. (Avis, 2016)

\subsection{Research Questions}

a) What are the social challenges learners residing in informal settlements in Katima Mulilo Town face in learning?

b) How can these challenges mention above be possibly dealt with?

The stated research questions and the theories of urbanisation discussed in the background alone cannot be sufficient to view this phenomenon. However, when coupled with literature, these social challenges learners face and ways to mitigate them can be found. In view of this, the literature related to this phenomenon is discussed in the following section

\section{Literature review}

\subsection{Learners in Informal Settlements and Their Challenges}

Learners, educators, parents, and families in informal settlement areas in Namibia in general and Katima Mulilo 
town in particular face many challenges. Living in dwellings in informal areas is often detrimental to the well-being of a learner (Verster, 2018). Three aspects need to receive attention in this regard, firstly the environment, secondly the challenges of education, and thirdly social challenges. Many school going children in Namibia today suffer from poverty and lacking basic essentials. These conditions make them feel worthless and neglected which in most cases forces them to resort to violence to restore their sense of power (Hartas, 2011).

Lack of financial resources also affects school attendance among the absolutely poor in developing countries as highlighted by Chinyoka (2014). Learners who are from poor backgrounds and who are suffering are more prone to dropping out of school as compared to those from well-off families. According to Chinyoka (2014), a certain study was conducted in rural China to ascertain the extent at which learners from well off families are in relation to their education as compared to their counterparts in destitute families revealed that 'poor and credit constrained children are three times more likely than other children to drop out of primary school. The researchers sought to establish if these findings are true regarding learners in informal settlements in Katima Mulilo town in Namibia. Child labour, poverty, bereavement, truancy and broken homes are sources of failure (Dzimiri \& Tendai 2018). There is a link between poverty and children's cognitive abilities and social-emotional competence, arguing that parents' decisions on the allocation of resources like money to purchase books and time spent on children in joint activities are considered investments that have the potential to enhance children's skills and language (ibid).

\subsection{Effects of Overcrowding on Learners in Informal Dwellings}

People live in shacks that are very small and most of them live in one roomed shacks in which all family members live (Msindo, Gutsa and Choguya, 2013). The legacy of more of colonialism and apartheid has created a unique burden for most families, who have to struggle with both economic and political oppression, resulting in an endless cycle of unemployment, poor housing, overcrowding and inadequate community services (De la Rey, et.al, 1997). The study is there to look at how this overcrowding affects learners in an informal setting. The nature and quality of the environment in which the child grows is of great importance for his/her development. The home as an environment plays a major role in socialising the child for adult life and the home is first and basic educating agent in the child's life (Bashman, 2008). Home background and community values can mar or make effective learning (Bhengu, 2009).

\subsection{Impact of Milieu Deprivation on Academic Achievement}

The concept milieu deprivation refers to a divergent variety of socio-economic and cultural factors impeding the milieu-deprived individual's freedom of choice and his/her right to the optimal use of his/her opportunities (Bashman, 2008). It is quite difficult for a child to achieve his/her potential in such a deprived and disadvantaged environment. The child himself/herself in a social environment is characterised by geographical-physical inadequacies, particularly in terms of the physical environment, the neighbourhood, housing, material goods and cultural goods; inadequate interpersonal communication, which does not enable the child to actualise his/her personal potential, especially his/her socio-communicative potential in full and the maintenance of low cultural standard (Pretorius and LeRoux, 2000). In the school situation these children often experience feelings of rejection because of other learners and educators' disapproval of their lack of cleanliness, wrong uniform, absenteeism, lack of exercise books and textbooks and what is also evident in squatter areas is the high rate of school drop-outs and those who never attended school (ibid). A child is environmentally deprived when language deficiencies limit his/her communicative possibilities in the dominant culture and when his/her particular experiential background limits him/her with regard to the acquisition of learning life content as in the dominant culture and is therefore unable to meet the demands of modern life (Hartas, 2011). It is the focus of this article to explore the extent to which these factors influence learners from informal settlements.

\subsection{Impact of Socio-economic Status (SES) on Academic Achievement}

Parent's socio-economic status is based on family income, parental occupation and social status in the community. It is believed that low SES negatively affects academic achievement because it prevents access to vital resources and creates additional stress at home (Hartas, 2011). The family provides its members with a social identity; children are born into their parents' social class. It is our assumption that children from informal settlements face many obstacles and challenges because of the social class into which they are born which is at the bottom of the social hierarchy, hence the need to examine these challenges through research. Socio-economic background is one of the key issues which are being majorly considered by researchers whenever factors influencing children's academic performance are being discussed. 


\subsection{Effects of Socio-economic Status (SES) on Academic Performance of Learners in Informal Dwellings}

Although there is no strong consensus on the conceptual meaning of socio-economic status, sociologists typically use this term to refer to relative position of an individual or family within a hierarchical social structure, based on their access to, or control over wealth, prestige and power (Giddens \& Sutton, 2013). Parent's socio-economic status is based on family income, parental occupation and social status in the community.

Socio-economic backgrounds of parents have been said to have intellectual credibility in terms of its contribution to educational attainment of the children (Gary, Julie, Frank \& John, 2000). There are different aspects of socio-economic background which are said to be indispensable to the growth and development of children's academic attainment. It is of great concern to educators, researchers and policy makers to acknowledge the extent to which students of low socio-economic positions appear to be disadvantaged or badly off their counterparts from higher socio-economic background in areas of academic performance, educational attainment, including acquisition of post-secondary school certificate (ibid). The United Nations' programme, Education For All movement (EFA) is intensively committed to the achievement of six main goals by 2015 namely early childhood care, primary education, literacy, gender equality and provision of quality education for children, youth and adult (UNESCO, 2010). The aim is to try and eradicate poverty and diminish the gap between learners from different SES. However, it is affirmed that when a relationship between educational attainment and socio-economic position exists, those pupils who appear to be from low socio-economic background encounter certain level of unfavourable situations while at school and thereafter in adulthood and this situation has been claimed to result into problems of human resource wastage, inefficiency of required occupational capabilities and consequently economic inefficiencies (Gary et.al, 2000). The inequalities are still there among learners of different socio-economic backgrounds hence the need for such studies.

A study by Garau and Sclar (2004) found that, people who live in informal settlements are often scientifically excluded from opportunities, decent employment, security, capacity, and empowerment that would enable them to gain better control over their health and lives. Lack of decent employment for them is manifested as most people living in informal settlement are street vendors (Roever, 2016). The implication is that they earn less money to sustain themselves to live in a standard way (Endjala \& Botes, 2020). For those who will find themselves employed they will either be security guards, domestic workers or cleaners (Ndumba, 2014). For many here, climbing out of poverty is almost impossible because most of them do not have alternative ways to sustain their living as they lack the necessary education required to land steady-paying jobs. On account of this, this makes their way of life intergenerational.

Informal settlement residents have a negative impact to their environment due to a lack of basic services. These results can be in the form of polluting the soil as there is no authentic refuse removal system; they end up dumping refuse everywhere. For instance, plastics which they use to carry food stuffs from the shops can be found everywhere in their locations. These end up in the soil disturbing the ecosystem as they do not decay. Worst still is that the delivery of infrastructural services such as hygiene is not up to standard (Amweelo, 2008). This means refuses or trashes are not picked out by the municipality due to the fact that most of the informal settlements are not registered as a result the environment will be left dirty.

Since there is lack of electricity, source of energy to cook, boil water for bathing, others use wood fuel. As it burns, it produces gases which end up in the atmosphere thereby raising global warming (Ali \& Sulaiman, 2008). All these contribute in a continued cycle of decline of standards of living for shanty dwellers and the effects affects the learners from these areas most as these social challenges spill to the schooling system.

Failure to provide these services adequately have resulted in many of the most well-known risks of rapid urbanization: threats to health, urban productivity and environmental quality. Lack of adequate infrastructural services create critical equity problems resulting in high costs which mostly affect the urban poor who are the majority living in squatter areas in terms of poor health, low productivity, reduced incomes and poor quality of life. Deficiency of these infrastructural services manifests pollution, diseases and economic stagnation. (Amweelo, 2008 )

The people who live in such settlements are prone to various infectious diseases such as tuberculosis, influenza, meningitis, malaria, diarrhoea and other intestinal diseases. Health risks in informal settlements increase due to lack of proper sewerage systems, river streams, canals, gullies and ditches and open spaces are the places where most human excrement and household waste ends up untreated (UN-HABITAT, 2010). This means there are no proper healthy facilities and low distribution of medication to affected people. Informal settlements remain detached from the rest of the city; people of informal settlements are highly neglected from those who are in high income houses (Turok, 2015).

The growth of urban slum areas in developing countries brought an increase in poverty as many poor, often illiterate 
and unskilled people leave rural areas to try and find employment in cities but they end up living in informal settlement where they afford the minimum standard of living (Govender, Barnes, \& Pieper, 2010). It also brought about a lot of noise from these settlements due to the uncontrolled existence of taverns. Too much noise generally distracts learners from learning or leads to sleepless nights by learners that affect their work in class and this is very common in informal settlements (City News, 2021).

\subsection{A Conceptual Framework of Social Challenges Faced by Learners Residing in Informal Settlements}

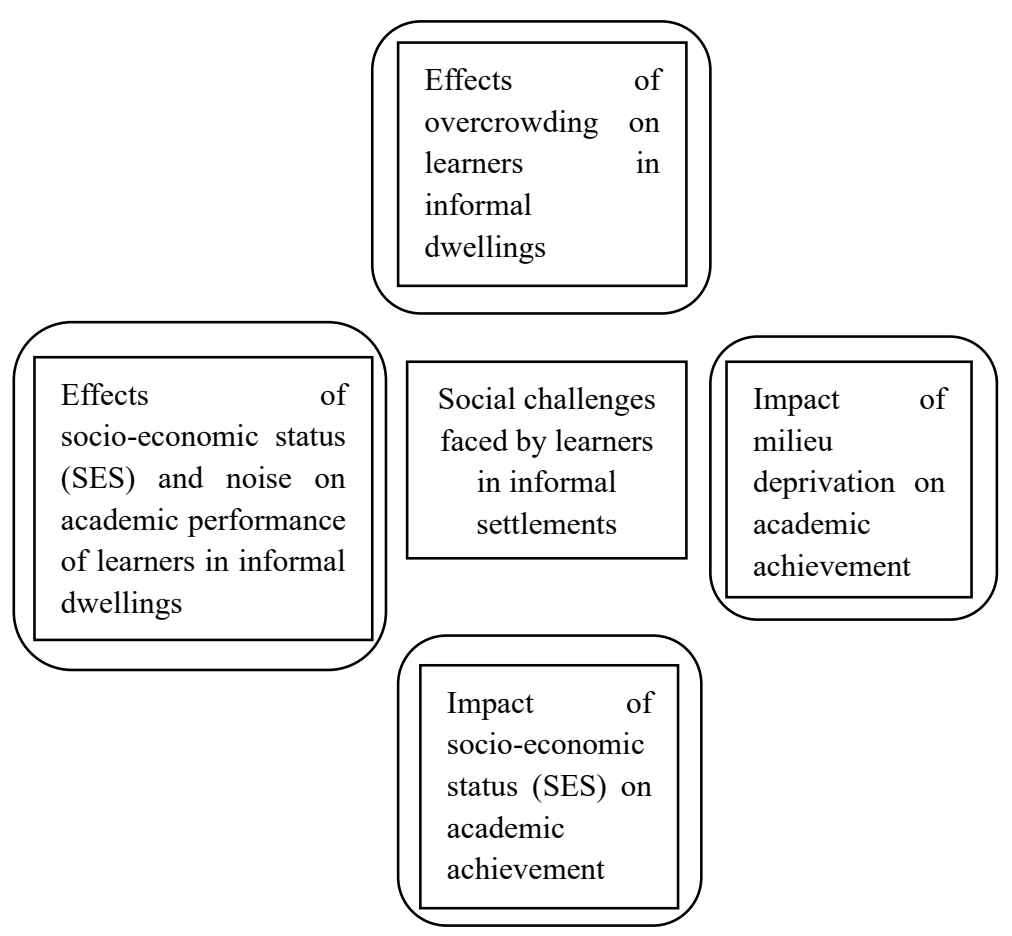

The social challenges faced by learners residing in informal settlements include the effects of overcrowding, milieu deprivation, impact of socio-economic status and the effects of socio-economic status (SES) and noise on academic performance of learners in informal dwellings.

\section{Methodology}

\subsection{Research Design}

Qualitative research approach was used to conduct this study. It examined phenomenon of informal settlement as they exist in a natural setting and it focused on participants' perspective. In addition to this it generalised the findings through involving few participants from all the informal settlements. Challenges experienced in these informal settlements are not exclusive but common in order for the researcher to understand the phenomenon. There is a need for critical analysis of the data collected on why things happen the way they do (Huchzemeyer, 2008). Qualitative research as explained by Green and Thorogood (2004) is characterized by its aims which relate to understanding some aspect of social life and methods and this allowed us to see how the social challenges affected learners from these areas. Moreover, it takes into account the lived experiences, hence enabling contextualization of the analysis of phenomenon.

\subsection{Population}

Gouverneur (2014) defines population as the targeted group of individuals with characteristics of interest. In this study, the population is the residents of all the five informal settlements of Katima Mulilo town.

\subsection{Sample}

Purposive sampling method was used as all people were residents of the five informal settlements of Katima Mulilo town. At least twenty-five people in total were purposefully selected with five persons per settlement to participate in the study. The sampled population made up of parents and learners, was then used to generate data using some research tools discussed below. Most of these parents were community leaders residing in the respective informal 
settlements. These parents were knowledgeable in the area of our investigation and we were able to collect a large quantity of data for this article.

\subsection{Data Collection Methods}

We used structured interviews to administer oral questions to different participants in which a list of predetermined questions was asked, with no variation and with a scope for follow up questions to responses that warrant further elaboration. Participants who have stayed in those informal settlements for more than five years were eligible for interview as these had now experienced these challenges for some time. Apart from interviews, observations were also used to collect data. Both face to face and focus group interviews were used to get appropriate information on the social challenges which these informal settlements are facing. Observation of these informal settlements was used and photos were also taken.

\subsection{Data Analysis}

A qualitative analysis of data was done using discovery and interim analyses strategies to analyse and code the data (McMillan \& Schumacher, 2006). Interview data was then transcribed and analysed using codes and then categorizing it into manageable themes. The names of participants and informal settlements where the study took place were kept anonymous.

\section{Data Presentation}

\subsection{Observation Data on the Social Challenges Learners Residing in Informal Settlements in Katima Mulilo Town Face in Learning}

The data which is presented below came as a result of using the observation instrument. The researchers moved around the area where the informal settlements are located. This data from observation is presented below. In Figure 1 , a structure of an informal settlement facility is shown.

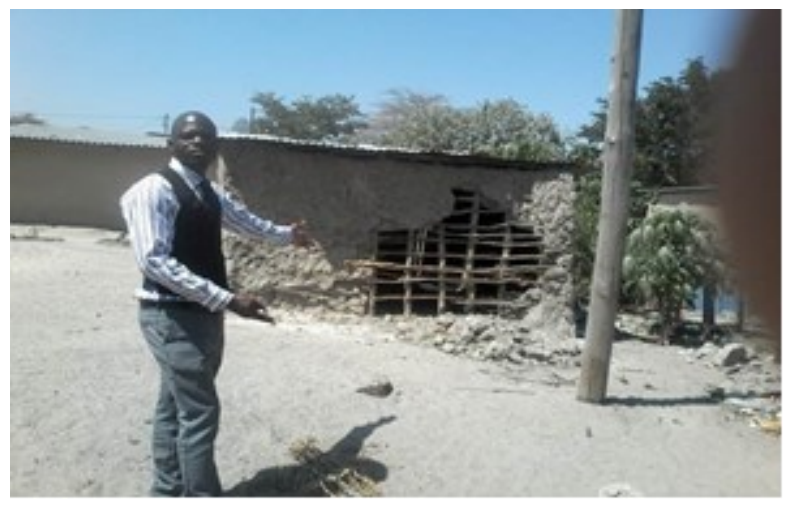

Figure 1. A Dwelling Structure Found in One of the Informal Settlements

The trend of housing in these areas is the same. This can be observed in all the five informal settlements. In some other informal settlements, the materials used for constructing houses vary depending on their ethnic groups. Others prefer structures where the walls and roof are all made of corrugated iron sheets. On account of lack of proper refuse removal system, garbage in these informal settlements are found strewn everywhere. This is evidenced from what is seen in Figure 2 below. 


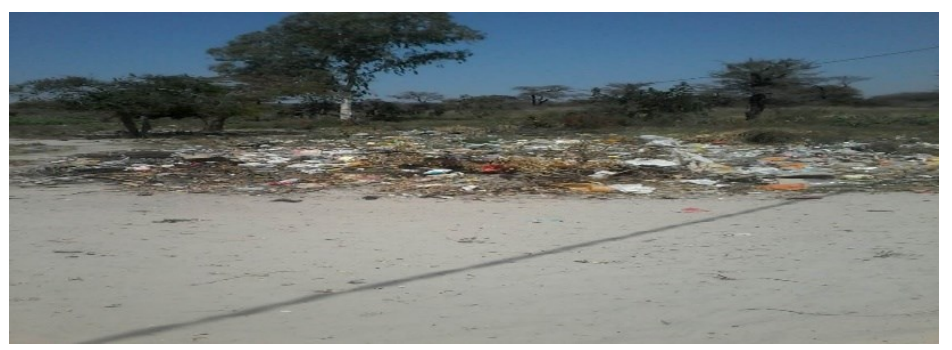

Figure 2. A Dumping Site in an Informal Settlement

The dumping site shown above is close to dwellings. This is evident from the fact that at the background, some dwellings are observed under the tree and beyond. However, these dwellings are so close to the dumping site. It has been pointed out in the literature that these residents do not have proper sanitary system. Figure 3 below shows a structure used for bathing purposes and also for helping one, when nature calls.
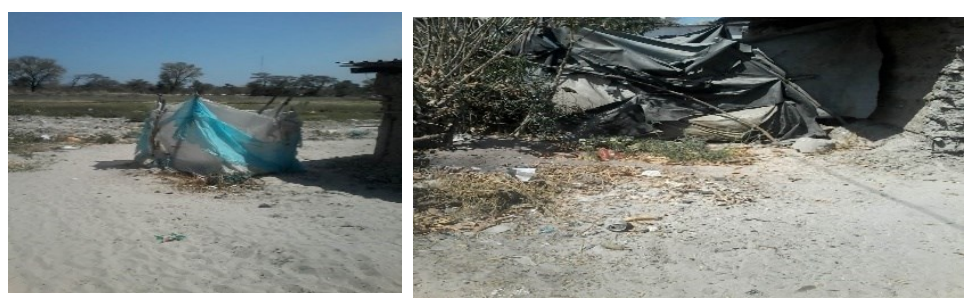

Figure 3. Structure for Bathing in One Informal Settlement

Such structures are common all over in the observed informal settlements. However, there is a variation on the materials used. Some use plastics and very few use corrugated iron sheets. In most of these structures most do not a have a roof and this exposes the contents to insects which are vectors which contribute in the carrying of infections from these structures to the settlers of these areas.

\subsection{Data from Interviews on the Social Challenges Learners Residing in Informal Settlements in Katima Mulilo Town Face in Learning}

Using interviews, four themes emerged and these are presented in Table 1 below. These were mainly; lack of proper infrastructure to support families, doing household chores, the issue of noise and bullying. These themes are supported by statements obtained from parents/guardians and learners residing in the informal settlements.

The themes obtained above were then related to the research questions to come up with the responses and then discussed. These discussions are in the section which follows, entitled discussion of findings to come up with response to the research questions. 
Table 1. Social Challenges Faced byLearners

\begin{tabular}{|c|c|}
\hline Emerging themes & Statements from data by participants \\
\hline \multirow[t]{5}{*}{$\begin{array}{l}\text { Lack of proper infrastructure to support } \\
\text { families }\end{array}$} & $\begin{array}{l}\text { "Here we are suffering, no toilets or shower. We only had built } \\
\text { ourselves these temporary structures as showers and we experience } \\
\text { crime when we go to relieve ourselves in bushes." }\end{array}$ \\
\hline & $\begin{array}{l}\text { "My children are suffering as you can see here, they lack many things } \\
\text { even food is a challenge, and they only eat two meals in a day. These two } \\
\text { that go to school walk a long distance to school because I cannot afford } \\
\text { to pay for their transport" }\end{array}$ \\
\hline & $\begin{array}{l}\text { "Electricity is also a problem; it is only in brick houses. We are really } \\
\text { suffering, if there is no moon at night, you cannot walk around during } \\
\text { the night due to criminals." }\end{array}$ \\
\hline & $\begin{array}{l}\text { "We have no school in this location, the only school we have is about } \\
\text { two and half kilometres away and during rainy season we normally } \\
\text { suffer and taxis don't always want to reach us here due to the condition } \\
\text { of our roads so it is really a challenge." }\end{array}$ \\
\hline & $\begin{array}{l}\text { "Our two roomed house does not have conditions for me to do my } \\
\text { school work as it exposes me to what is happening outside when I am } \\
\text { doing my school work." }\end{array}$ \\
\hline Doing household chores & $\begin{array}{l}\text { "My children are suffering here because they look for firewood and also } \\
\text { fetch water every day after school." }\end{array}$ \\
\hline The issue of noise & $\begin{array}{l}\text { "There is a problem of noise from many taverns which are surrounding } \\
\text { us and this disturbs us so much from doing our studies here and this } \\
\text { happens day and night." }\end{array}$ \\
\hline Bullying & $\begin{array}{l}\text { "Sometimes my children are teased and bullied at school because they } \\
\text { go to school without all the things required. They cannot learn well at } \\
\text { school because they are tired after walking a long distance to school." }\end{array}$ \\
\hline
\end{tabular}

\section{Discussion of the Findings}

\subsection{Introduction}

The findings in this study as revealed from the themes suggest that learners living in informal settlement environment face many challenges at home as shown in the sentiments from where the themes were synthesized.

\subsection{The Theme of Lack of Proper Infrastructure to Support Families}

The observation instrument reveals that there is lack of proper infrastructure to support families as Figure 1, Figure 2 and Figure 3 show. These show that there is no proper housing facility as the one shown in Figure 1 is already having some dents and this does not support a learning environment for learners. Such type of a house exposes learners to what is happening outside when they are doing homework or busy reading in the house. This is in opposition to what Bodo (2015) suggests that people move into urban areas in search of better living conditions as observation reveal that these migrants end up living in houses whose walls are made up of pole and dagga and roof made up of corrugated zinc. However, because the materials are not strong enough they end up giving in when affected by some environmental conditions such as rain or wind. So, such social challenge learners residing in informal settlements in Katima Mulilo Town face make them lag behind in learning and this is also supported by the learner as revealed in Table 1 column 2 in the last statement and is a view (Msindo, Gutsa and Choguya, 2013) put forward as a challenge which comes with rural to urban migration.

On account of lack of infrastructure, rubbish is thrown all over the informal settlements as shown in Figure 2 . This exposes learners and their families to diseases. As they contract diseases, they do not attend school regularly and this reduces their chances of interacting with other knowledgeable individuals. Instead of getting a job to sustain a family, parents and their dependants end up living in deplorable conditions and this is in contradiction with the self generated urbanisation theory Hawley (1981) proposes. 
Finally, on social challenges brought by lack of infrastructure to support learning observations interviews reveal that there are no proper ablution facilities as Figure 3 supports. This is also revealed in Table 1 column 2 as the parents reported that there are no toilets or bathing facilities for them.

\subsection{Theme of Doing Household Chores}

Observations and interviews conducted revealed that learners who are supposed to spend most of their time doing their school work spent a large amount of their time when at home doing household chores. For instance, learners were observed assisting in putting the poles and zinc roof of some of the dwellings in one of the informal settlements. In the case of a girl child, some were seen selling traditional bear and this we see it as a way of paving their way to be street prostitutes. When a girl sells traditional beers, she interacts with adult members of the community who induce her into illicit activities. All these constitute what we refer to as child labour. According to the International Labour Organisation (ILO, 2002), all economic accomplishments conducted by persons under the age of 15, irrespective of their job-related status, except household work in parents/carers homes, is prohibited.

Learners work across a variety of employment areas in informal residential areas. Some include agriculture: weeding gardens of other affluent people, manufacturing, working in carpentry shops, street trading, domestic work (Ashagrie, 1998). Several children work since they perceive benefits of working as superior than those of attending school. These benefits can include monetary return, the chance to acquire an expertise, a feeling of independence, and an elevated self-esteem (Woodhead, 2001). The family may also perceive this as a relief since they are unable to afford either the actual costs or the opportunity costs of education. These beliefs may lead learners into not attending school. As a result of this, learning is compromised and school leadership is challenged as they aim to ensure that every learner is at school.

Work and school are not mutually exclusive and this is evident from what is obtained from some of the learners as revealed in Table 1. There were reports as manifested in Table 1 that they do not have sufficient time to do school work as some of their time is used to do household chores. This report also reveals that some learners value school but because of their circumstances they are forced to do household chores to assist their parents.

The above sentiments from learners would actually mean that most parents of children living in the informal settlement environments cannot afford to fully finance their children's education because of poverty caused by high rate of unemployment among most households in the informal settlements. Most of the households survive on social grants and only a few are working in the formal sectors or self- employed. Poverty stricken home environment were according to Bhengu (2009) found to have serious implications on children's access to education. The findings of this study also revealed that most learners walk to school every day. Their guardians cannot afford to pay for their transport because of poverty. A conclusion drawn is that learners from an informal settlement, because of lack of a good home environment, they do not do their homework, they come to school hungry and that they are always absent from school and this acts as one of the social challenges learners coming from informal settlements face.

\subsection{Theme of the Issue of Noise}

The home environment was found not to be conducive in raising young children as there were many beer drinking outlets. Families that live in informal settlements, with the associated poverty, unemployment and inadequate and overcrowded housing, often find they are constantly disturbed by noise coming from the points where beer is sold. Beer outlets come as a result of the need of parents to raise money for use in the raising of the family. So to meet this demand, characterized by shortage of money, parents come with other alternatives such as selling traditional beer where noise is at its maximum and learners cannot be in a position to do their school work. This lack of finance results in the learner not having important materials such as text books, and water and sanitation facilities. The lack of such facilities has critical implications on the education of a child at home. This finding was similar to that of City News (2019). They expressed the views of residence of Primrose who complained about the loud music that has been coming from taverns in the informal settlements.

The other observation brought to our attention was when we discovered that these shacks were closely packed together and there was no space for children to play. There were no playgrounds for children and the sanitation in these areas was poor. The ablution services were poor and many families were sharing a single toilet and with some of them still using either the unhealthy bucket system or nearby bushes when nature calls. The participants highlighted a number of effects that overcrowded housing had on children, such as deprivation of their rights. A peaceful environment for concentrating and studying at home is almost missing. The entire surrounding environment was found to be dirty, filthy and unhygienic for raising children and this makes these informal settlements lack harmony. The land was polluted almost everywhere because the camp is close to the dump site (in case of one informal settlement). 


\section{Conclusion}

It can be seen that communities in these informal settlements should opt for self-organization especially communities with educated people like teachers. This initiative to bring sanitation into these communities to alleviate social challenges learners face could be backed up by the media, local government and international NGOS. This process of self-organization has had many positive outcomes. Urban development projects should be located closer to these areas to benefit from their labour. The town council should continue to assist with the special planning, and provide water and electricity and charge a minimum amount as suggested by Lux (2009). Researchers like Nelson (2013) have suggested that these communities should organize themselves and demand equal treatment when required.

\section{Recommendations}

To alleviate the social challenges learners encounter, the town council with informal settlements must complete projects of installing sewage lines and water system. In doing so, people residing in informal settlements could have better sewage system which might prevent the incubation of organisms which causes diseases and then prevent learners from absenting themselves from school when they are sick. If the local authority where these informal settlements are located have financial challenges to build sewage pipes, then they must enforce some laws where informal settlements residents are compelled to build pit latrines or septic tanks and the town council should meet the residents, half-way. This can be achieved through providing them with some building materials. Also, the building of quality roads which are dust-free and which can last long without pot holes allows learners to move from these areas to school without some challenges since currently the roads are full of water and this makes movement very difficult.

Order need to be put in place so that residential dwellings are in proper streets and in one particular area and points where people are selling placed away from them to reduce noise which interfere with learners when they are at home doing school work. The current crowded structures seen do not provide conducive conditions for learners to do their work at home.

When the above mentioned facilities are in place, then schools can be built in these areas. When schools are in place, learners in these communities can be enticed to go school since the government provides meals in schools. Most of these learners fail to attend school since they are hungry as most parents do not work or have a stable job. Some suggestions from residence of informal settlement one is that the town council and the entire government should increase the number of projects where people can work and earn money to sustain their needs. These projects may include poultry farming and gardening projects. They also suggested that the town council should try to fund projects which will teach people some surviving skills. These findings are in line with the research done by Gulyani, Talukdar and Jack (2010) in Dakar, Johannesburg and Nairobi. Business organizations like banks should at least plough back to the communities like these informal settlements by giving them loans which could help them to start some small scale businesses to alleviate poverty.

\section{References}

Ashagrie, K. (1998). Statistics on working children and hazardous child labour in brief. International Labour Office, Geneva. Retrieved from www.ilo.org/publi/english/standards/ipec/simpoc/stats/child

Avis, W. R. (2016). Urban Governance (Topic Guide). Birmingham, UK: GSDRC, University of Birmingham.

Bashman, L. E. (2008). Perspectives of Teachers on the problem of child sexual abuse in squatter camp. Nelson Mandela University. Retrieved from: http://hdl.handle.net/10948/684

Bhengu, T. B. (2009). Educational distress of a child from a deprived milieu. University of Zululand

Bodo, T. (2015). Rapid urbanisation problems and coping strategies in Port Harcourt metropolis, Rivers State, Nigeria. Master's thesis, University of Port Harcourt, Choba, Rivers State.

Bodo, T. (2019). Rapid urbanisation: Theories, causes, consequences and coping strategies. Annals of Geographical Studies, 2(3), 32-45.

Bradshaw, W. (1987). Urbanization and underdevelopment: A global study of modernization, Urban bias and economic dependency. American Sociological Review, 52(2), 224-239. https://doi.org/10.2307/2095451

Chinyoka, K. (2014). Influence of Home based factors on academic performance of girl learners from poverty stricken families: A case of Zimbabwe. Mediterranean Journal of Social Sciences, 5(6), $223-232$. https://doi.org/10.5901/mjss.2014.v5n6p223 
City News (2019). Residents still sleepless due to blaring music from informal settlements. Retrieved from https://germistoncitynews.co.za/208478/residents-still-sleepless-due-to-blaring-music/

De la Rey, C., Duncan, N., Shefer, T., \& Van-Niekerk, A. (1997). Contemporary issues in human development: A South African focus. Johannesburg: International Thomson Press.

Endjala, T., \& Botes, L. (2020). Surviving like a bird. African Sociological Review, 24(1), 151-173.

Dzimiri, C., \& Goso, T. (2018). Challenges faced by learners who live in squatter camps: A case of one primary school in Rustenburg province of South Africa. International Journal for Research in Educational Studies, 4(5). Great Zimbabwe University

Gary, M., Julie, M., Frank, J., \& John, A. (2000). The Measurement of Socioeconomic Status for the Reporting of Nationally Comparable Outcomes of Schooling. Canberra: Australian Council for Educational Research and Sociology Program Research School of Social Sciences Australia National University.

Giddens, A., \& Sutton, P. W. (2013). Sociology. Cambridge: Polity Press.

Gouverneur, D. (2014). Planninng and designing for future informal settlements. Routledge. https://doi.org/10.4324/9781315765938

Gulyani, S., Talukdar, D., \& Jack, D. (2010). Poverty, living conditions, and infrastructure access. Geneva: Hartas, D. (2011). Families' social backgrounds matter: Socio-economic factors, home learning and young children's language, literacy and social outcomes. British Educational Research Journal, 37(6), 893-914. https://doi.org/10.1080/01411926.2010.506945

Hawley, A. (1981). Urban society: An ecological approach. New York: Ronald.

Huchzemeyer, M. (2008). Challenges facing informal settlement. Cape Town: Witwatersrand.

International Labour Office, (2002). Every child counts. New global estimates on child labour. Geneva: ILO.

Jiusto, S. (2012). Responding to homelessness:Sguatting-Developing world. New York: International Encyclopedia of Housing and Home, Susan Smith(edu) Elsevier. https://doi.org/10.1016/B978-0-08-047163-1.00386-6

Kasarda, J. D., \& Crenshaw, E. M. (1991) Third world cities: Dimensions, theories and determinants. Annual Review of Sociology, 17, 467-501. https://doi.org/10.1146/annurev.so.17.080191.002343

McMillan, J. H., \& Schumacher, S. (2006). Research in education: Evidence-based inquiry (6th ed.). Boston, MA: Allyn and Bacon, M. (2009). Housing Police: An End or a New Beginningg. New York: Open Society Institute.

Msindo, P. D., Gutsa, I., \& Choguya, N. Z. (2013). Squatter settlements: An urban menace in Zimbabwe? Examining the factors behind the continued resurfacing of squatter settlements in Epworth suburb. Harare: University of Zimbabwe

Nelson, B. (2013). Making an issue of child abuse: Political agenda setting for social problems. ISBN 9780226572017.

Pretorius, J. W. M., \& Le Roux, J. (2000). Socio pedagogics 2000. Pretoria: Van Schaik Publishers.

Roever, S. (2016). Informal trade meets informal governance. Cityspace, 18(1), 27-46.

Smith, D. A. (1996). Third world cities in global perspective: The political economy of uneven urbanization. Boulder, Colorado: Westview Press.

UNESCO. (2010). Reaching the marginalized: Education for all global monitoring report. Paris: UNESCO.

Woodhead, M. (2001). The value of work and school: a study of working children's perspectives. In Lieten G. K., White B. (Eds.), Child labour: policy options. Amsterdam: Aksant Academic Publishers.

\section{Copyrights}

Copyright for this article is retained by the author(s), with first publication rights granted to the journal.

This is an open-access article distributed under the terms and conditions of the Creative Commons Attribution license (http://creativecommons.org/licenses/by/4.0/). 